\title{
Searching for pattern and mutation in the Drosophila genome with a P-lacZ vector
}

\author{
Ethan Bier, Harald Vaessin, Susan Shepherd, Kevin Lee, ${ }^{1}$ Kimberly McCall, ${ }^{2}$ Sandra Barbel, Larry \\ Ackerman, Robert Carretto, Tadashi Uemura, ${ }^{3}$ Ellsworth Grell, Lily Y. Jan, and Yuh Nung Jan \\ Howard Hughes Medical Institute and the Departments of Physiology and Biochemistry, University of California, San \\ Francisco, California 94143 USA
}

\begin{abstract}
A P-element vector has been constructed and used to generate lines of flies with single autosomal P-element insertions. The lines were analyzed in two ways: (1) the identification of cis-acting patterning information within the Drosophila genome, as revealed by a lac $Z$ reporter gene within the $P$ element, and (2) the isolation of lethal mutations. We examined 3768 independent lines for the expression of $l a c Z$ in embryos and looked among these lines for lethal mutations affecting embryonic neurogenesis. This type of screen appears to be an effective way to find new loci that may play a role in the development of the Drosophila nervous system.
\end{abstract}

[Key Words: P element; lacZ; mutagenesis; cell marker; Drosophila; pattern]

Received May 30, 1989; revised version accepted July 11, 1989.

One approach to studying development is to obtain genetic variants that are defective in some crucial step. This type of genetic analysis has been very successful in identifying virtually all of the zygotic loci required for the early stages of segmentation during embryogenesis in Drosophila melanogaster (Jürgens et al. 1984; Nüsslein-Volhard et al. 1984; Wieschaus et al. 1984). Besides chemical mutagenesis, transposon tagging has been used as a mutagen and allows rapid cloning of genes of interest (Bingham et al. 1981; Rubin et al. 1982; Kidwell 1986).

Recently, a scheme wherein single P elements are mobilized to new chromosomal locations has been implemented successfully (Cooley et al. 1988). The essential nature of this approach is to use two separate P elements to provide the two functions necessary for transposition. The first is a genetically marked P element that is defective in production of transposase but contains the ends required for its own transposition. The second is a P element with functional transposase activity but a much reduced likelihood for its own transposition (Robertson et al. 1988). Transposition of the marked P element then is initiated by crossing flies that carry only the marked $P$ element to those that harbor only transposase. Insertions generated by this scheme are recovered in flies lacking tranposase activity and are therefore genetically stable.

P-element vectors also have been used recently to search for cis-acting sequences which confer tissue-specific expression of a $\beta$-galactosidase $(1 \mathrm{ac} Z)$ fusion gene driven by the weak promoter of the P-element transpo-

Present addresses: ${ }^{1}$ Department of Biology, Massachusetts Institute of Technology, Cambridge, Massachusetts 02139 USA; ${ }^{2}$ Department of Genetics, Harvard Medical School, Boston, Massachusetts 02114 USA; ${ }^{3}$ Department of Biophysics, Kyoto University, Kyoto, Japan. sase gene (O'Kane and Gehring 1987; Ghysen and O'Kane 1989|. Interestingly, the majority of independent $\mathrm{P}-l a c Z$ insertions lead to nonubiquitous patterns, many of which include or are limited to nervous tissue. An exciting possibility is that some of the patterns obtained reflect expression patterns of genes that are near the site of the P-element insertion.

To identify genes required for proper development of the embryonic nervous system in embryos of Drosophila melanogaster, we combined the mutation and patternhunting strategies described above and conducted a genetic screen with a newly constructed P-element vector. Our P-lacZ vector, P-lacW, has features of vectors used by Cooley et al. (1988) and O'Kane and Gehring (1987). Thus, P-lacW includes a P-transposase lacZ fusion gene for pattern detection and bacterial plasmid sequences for rapid cloning. The eye color gene white was used for the marker gene, which permits rapid scoring of recessive lethal insertion mutations (Pirrotta 1988). P-lacW was mobilized from the $\mathrm{X}$ chromosome to autosomes in 3768 independent lines. These lines were scored as homozygous viable or lethal. Embryos from each line also were stained with X-Gal to determine the patterns of $l a c Z$ expression. To identify mutations that modify the stereotypic array of neurons in the embryonic peripheral nervous system (PNS) (Hertweck 1931; Campos-Ortega and Hartenstein 1985; Ghysen et al. 1986; Bodmer and Jan 1987; Hartenstein 1988; Bodmer et al. 1989), we labeled embryos from the recessive lethal lines with an anti-horseradish peroxidase-antiserum (anti-HRP), which marks the surface of all neurons (Jan and Jan 1982).

This report describes the types of lacZ expression patterns found, with particular emphasis on neuronal patterns. A brief summary of results from the anti-HRP 
screen of the lethal lines is also presented. Future potential uses of this pattern/mutation-hunting scheme are discussed. The evolutionary implication of the richness of pattern in the genome is also considered.

\section{Results}

\section{The P-lacW vector}

A map of P-lacW is presented in Figure 1A. The transposable portion of P-lacW contains a bacterial origin of replication and the $\beta$-lactamase gene coding for ampicillin resistance at its $3^{\prime}$ end. This feature permits easy cloning of DNA flanking the insertion site of P-lacW /Cooley et al. 1988). The mini-white gene (Pirrotta 1988) has been inserted in the middle of P-lacW. At the $5^{\prime}$ end, the P-element transposase gene has been fused to the lac $Z$ gene at approximately the same position as in the P-lacZ vector used by $\mathrm{O}^{\prime} \mathrm{Kane}$ and Gehring (1987) to detect patterns. Mini-white provides three major advantages as a genetic marker. First, flies heterozygous for mini-white in a genetic background null for the white locus generally have orange eyes, whereas flies homozygous for the same element have red (i.e., nearly wild type) eye pig. mentation. The dosage dependence of eye color on the mini-white gene arises from the subthreshold activity of this altered version of the white gene. In the majority of cases, this feature permits rapid scoring of flies heterozy. gous or homozygous for a P-lacW insertion, in contrast to rosy vectors, which yield the same eye color in heterozygotes and homozygotes. Second, once an element has been inserted in a location of interest, screening for loss of eye pigmentation can lead to isolation of revertants with P-element excisions that are either precise or inexact. Finally, mini-white is a small gene $(\sim 4.1 \mathrm{~kb})$, compared to rosy $(\sim 8 \mathrm{~kb})$, and allows the construction of a smaller vector that should jump more efficiently than larger ones (Spradling 1986).

\section{Mobilization of P-lacW to autosomal sites}

The genetic scheme used to mobilize P-lacW to autosomal sites is shown in Figure 2. Five lines were chosen with $\mathrm{P}-\mathrm{lacW}$ at different positions on the $\mathrm{X}$ chromosome as the source for P-lacW in the genetic jumping scheme described below, in case P-lacW jumping to autosomal sites was biased by the initial chromosomal location. The P-lacW in these lines could be mobilized at high frequency in the presence of a transposase source (Fig. $1 \mathrm{~B}$; see Methods). Similar to results found in the screen of Cooley et al. (1988), 11\% of third chromosome insertions were lethal. Of the second chromosomes that harbor P-lacW, however, 17\% are homozygous lethal. Mutations not associated with P-lacW have been observed in at least two cases, even though we isogenized all target chromosomes prior to our jumping scheme to avoid the retrieval of background lethal mutations (for discussion, see Cooley et al. 1988). These types of lethal mutations may account for the greater frequency of second versus third chromosome lethal mutations, because mutations on the second, but not on the third,

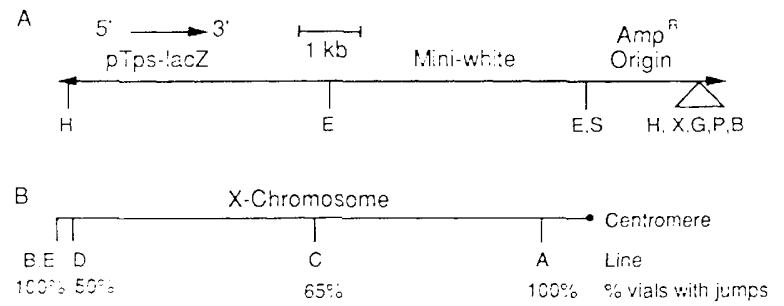

Figure 1. (A) Features of P-lacW. The transposable portion of $\mathrm{P}-\mathrm{lac} W$ is $10.6 \mathrm{~kb}$ long. At the $5^{\prime}$ end of the transposon is the P-element transposase-lacZ fusion (pTps-lacZ), which is followed by the mini-white gene (in the same orientation for transcription). At the 3' end of P-lacW there is the plasmid origin of replication (Origin) and the $\beta$-lactamase gene $\left(A \mathrm{mp}^{\mathrm{R}}\right)$. The plasmid sequences are bounded by two linker sequences containing EcoRI and SaclI sites in one and unique sites for $\mathrm{XbaI}$, $B g l$ II, PstI, and BamHI in the other. These restriction sites permit rescue of genomic sequences on either side of the integration site. Restriction enzyme abbreviations: $(\mathrm{H})$ HindIII; $(\mathrm{E})$ EcoRI; (S) SacII; (X) XbaI; (G) BglII; (P) PstI; (B) BamHI. (B) X chromosome starting sites for P-lacW. P-lacW insertions into five different sites on the $\mathrm{X}$ chromosome were used in the jumping scheme. Their locations on the $\mathrm{X}$ chromosome are indicated. All lines were tested for the fraction of crosses that gave rise to autosomal jumps in preliminary experiments (see Methodsl. No obvious differences in autosomal insertion site bias were seen for the various start sites. The recombination map positions for the different lines are: $60.7(\mathrm{~A}) ; 0.0(\mathrm{~B}) ; 32.0$ $|\mathrm{C}| ; 2.2(\mathrm{D})$; and $0.0(\mathrm{E})$.

chromosome were balanced at all times (Fig. 2). It is plausible that P-lacW insertions on the third chromosome, unlike those on the balanced second chromosome, would have been separated often by recombination from non-P-lacW mutations.

\section{Profile of embryonic lacZ staining patterns in P-lacW insertion lines}

The different classes of embryonic lac $Z$ staining patterns and the number of independent insertions in the different classes are listed in Table 1 . At least $64 \%$ of the lines express $l a c Z$ in embryos. This expression is nuclear, probably because $l a c Z$ in $P-l a c W$ is fused to transposase that is a nuclear protein. In the majority of lines, $l a c Z$ expression is uneven in different cell types; some lines show tissue-type restricted patterns, others show position-specific patterns, and yet others show more complicated (although always reproducible) patterns. Moreover, in a significant fraction (31\%) of the 3768 lines, lac $Z$ expression includes or is restricted to portions of the nervous system. In some cases, the same or very similar patterns of $l a c Z$ expression are induced by P-lac $W$ insertions at different locations. For instance, 42 independent $\mathrm{P}-\mathrm{lac} W$ insertions give rise to $l a c Z$ expression in 'all neurons.' Twenty-four of these insertions appear to express $l a c Z$ exclusively in neurons, and they map to 12 different chromosomal locations.

Examples of position-specific lac $Z$ expression are shown in Figure 3 . These examples include a variety of segmentally repeated stripe patterns (Fig. 3A-D), ex- 


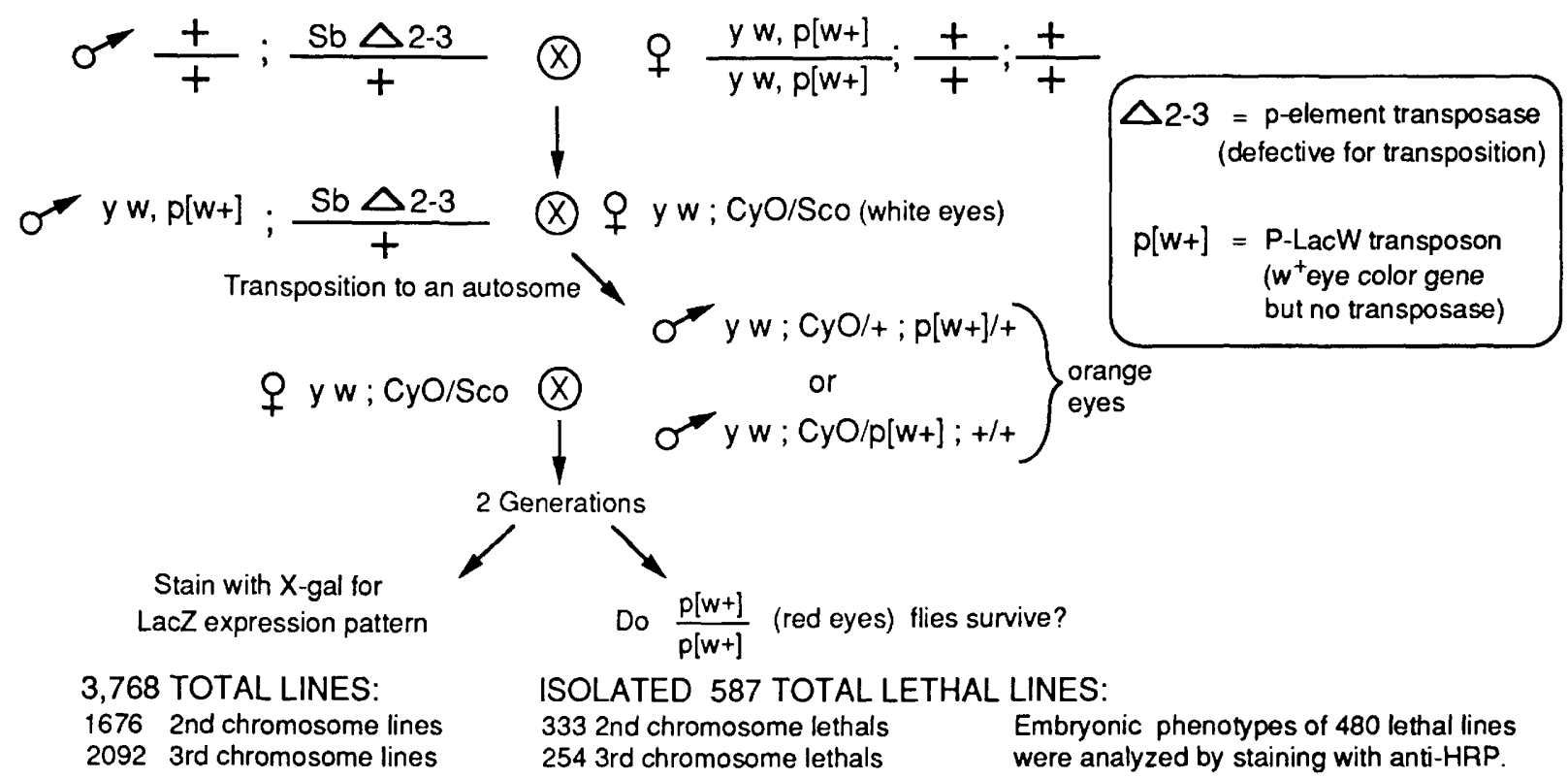

Figure 2. Genetic scheme for mobilization of P-lacW. The details of the scheme are provided in Methods. Relevant genetic symbols are as follows: $(y)$ yellow marker for body and bristle color; $(w)$ mutation defective for white gene function yielding white eyes; $\mathrm{CyO}$ a second chromosome balancer (which represses recombination) marked with the dominant Cy wing mutation; Sco a dominant second chromosome marker seen as a loss of scutellar bristles; $\Delta 2-3$ an altered form of $P$ element with the last intron deleted leading to somatic, as well as germ-line, expression of transposase. This particular $\Delta 2-3$ insertion is immobile (Robertson et al. 1988).

pression by cells along the ventral midline (Fig. 3E,F) or by cells in dorsal tissue (Fig. 3G,H), patterns of expression in the thorax and the abdomen (Fig. 3I-L), and expression that is restricted to head and tail (Fig. 3M,N).

$l a c Z$ staining lines have been found that serve as markers for essentially every known tissue type, including gut, salivary glands, trachea, heart, muscle, the amnioserosa, oenocytes, glia (Fig. 4A-J), epidermis, yolk, and gonad (not shown). There are also lines with lacZ expression in nearly all embryonic cells. Many PlacW markers are useful in delineating the development of particular structures. For instance, tracheal development can be followed from the early tracheal pit stage, through the stages of invagination, to the formation of the connected tracheal system (Fig. 5A-D). The ontogeny of a migratory cell type also can be traced from the first appearance of these cells in the anterior portion of the embryo to their later, scattered positions throughout the embryo (Fig. 5E,F). Similarly, the glial cells and their precursors in the CNS and periphery may be observed throughout development (not shown). In the nervous system, a number of lines feature $1 a c Z$ expression in all neurons of the CNS and PNS (Fig. 6A), in all neurons of the CNS (Fig. 6B), in glia (Fig. 6C), in parts of the brain (Fig. 6D), and in various other subsets of cells in the CNS and PNS (e.g., Fig. 6E-J). Indeed, the bulk of the nervous system staining lines mark subsets in the CNS.

P-lacW insertion lines also were found that express lacZ in the entire PNS (Fig. 7B,C) or in specific subsets (Fig. 7F-I). For instance, the external sensory organ is comprised of a neuron, an inner support (glia) cell, and two outer support cells that form the hair and socket.
The outer support cells are marked in one line (Fig. 7F), whereas the inner support cell is labeled in another line (not shown). The chordotonal stretch receptor organ also consists of four cells. The neuron has its dendrite tightly wrapped by a sheath cell and presumably is anchored to fixed locations underneath the epidermis by the ligament cell and cap cell on either end. Different P-lacW insertion lines show lac $Z$ expression in the neuron, the sheath cell, the cap cell, all three support cells, or all four cells of the chordotonal organ (Fig. 8A-E). In contrast to the external sensory neurons and the chordotonal neurons, the type II neurons have multiple arborized dendrites. Exclusive expression of lacZ in type II neurons also has been observed in particular P-lacW insertion lines (Fig. $7 \mathrm{H}, \mathrm{I}$ ).

lac $Z$ expression is not limited to embryonic stages and can be visualized in imaginal discs, in late larval CNS, in late pupae just prior to eclosion, and in isolated tissues such as the gonads. Preliminary observations indicate that some of the lines showing weak or no $\beta$-galactosidase staining in embryos express $l a c Z$ in the adult nervous system (G. Technau, pers. comm.). The lacZ expression patterns in these structures are currently under study and will be reported elsewhere.

\section{What do the lacZ expression patterns represent?}

It is important to determine how frequently lacZ expression reflects the endogenous expression patterns of genes near the sites of P-lacW insertion. There is not enough information to answer this question at this time; however, good correlations between lacZ expres- 
Table 1. Frequency of various lacZ staining patterns

\begin{tabular}{|c|c|c|}
\hline $\begin{array}{l}\text { lacZ expression } \\
\text { pattern }\end{array}$ & $\begin{array}{l}\text { Total number } \\
\text { of lines }\end{array}$ & $\begin{array}{l}\text { Exclusive } \\
\text { staining }\end{array}$ \\
\hline \multicolumn{3}{|l|}{ Position type } \\
\hline stripes (all periodicities) & 135 & 36 \\
\hline anterior + posterior tip & 32 & 21 \\
\hline anterior tip & 61 & 17 \\
\hline posterior tip & 1 & 0 \\
\hline dorsal & 14 & 5 \\
\hline dorsolateral & 2 & 0 \\
\hline lateral & 8 & 2 \\
\hline ventral & 1 & 0 \\
\hline thorax + abdomen & 5 & 1 \\
\hline thorax $>$ abdomen & 2 & 2 \\
\hline \multicolumn{3}{|l|}{ Tissue type (not neural) } \\
\hline gut (total) & 254 & 158 \\
\hline hindgut & 31 & 13 \\
\hline midgut & 16 & 12 \\
\hline salivary glands & 77 & 36 \\
\hline epidermis & 65 & 10 \\
\hline yolk & 31 & 16 \\
\hline trachea & 17 & 4 \\
\hline anal plate & 15 & 3 \\
\hline muscle & 11 & 2 \\
\hline heart & 11 & 0 \\
\hline gonads & 11 & 0 \\
\hline fat body & 9 & 7 \\
\hline amnioserosa & 7 & 2 \\
\hline oenocytes & 7 & 0 \\
\hline border cells & 3 & 0 \\
\hline garland cells & 1 & 0 \\
\hline glial cells & 6 & 1 \\
\hline \multicolumn{3}{|l|}{ General } \\
\hline weak general/background & 1211 & - \\
\hline moderate-strong & 49 & 34 \\
\hline \multicolumn{3}{|l|}{ Neural } \\
\hline all neurons & 42 & 24 \\
\hline total with CNS staining & 745 & 205 \\
\hline CNS subsets & 93 & 34 \\
\hline brain & 194 & 63 \\
\hline brain lobes & 5 & 2 \\
\hline antennal maxillary complex & 137 & 16 \\
\hline all PNS & 39 & 3 \\
\hline all PNS + support cells & 12 & 10 \\
\hline PNS subsets & 48 & 5 \\
\hline VNS & 37 & 3 \\
\hline sensory organs & 21 & 0 \\
\hline chordotonal organs & 28 & 2 \\
\hline external sensory organs & 4 & 0 \\
\hline multiple dendrite neurons & 6 & 2 \\
\hline BD neurons & 1 & 0 \\
\hline
\end{tabular}

The number of transformants with various $l a c Z$ expression patterns are listed. Numbers in the second column indicate numbers of lines with lacZ expression in the tissue identified in the first column; the categories may overlap. Thus, to derive statistics such as the total number of lines with nervous system expression, it is necessary to eliminate the overlap to avoid double counting. Computer sorting has permitted such calculations. Often expression is not exclusive to a tissue. The numbers in the third column, on the other hand, indicate the number of lines that express $l a c Z$ only in that tissue. In general, the number of lines expressing $l a c Z$ in a complex tissue is greater than that in simple structure comprised of a few cell types. CNS includes neurons and glia, and PNS includes neurons and support cells. sion patterns and known genes have been observed in several cases.

One transformant line obtained when P-lacW initially was injected into embryos is an insertion of P-lacW, $\sim 100$ bp upstream from the transcription start site of at least one of the three known transcripts of the elav (embryonic lethal abnormal visual system) gene at $1 \mathrm{~B}$ (S. Robinow, pers. comm.). lac $Z$ expression in this insertion is in the same direction as elav transcription (Fig. 9A). This insertion leads to $\beta$-galactosidase expression in all neurons. elav transcripts have been found in most, if not all, neurons by in situ hybridization to tissue sections (Campos et al. 1987; Robinow and White 1988). Moreover, the monoclonal antibody mAb 44Cll (Bier et al. 1988), which recognizes some epitope of the elav gene product (Robinow et al. 1988), shows a staining pattern identical to the lac $Z$ expression pattern in this line (Fig. $9 \mathrm{~B}, \mathrm{Cl}$. This antibody also reveals that the insertion causes a reduced level of elav protein in the apparently wild-type pattern in homozygous embryos, although such embryos develop into adult flies.

Two independent insertions of P-lacW have been found in the $5^{\prime}$ end of the Drosophila cyclin $A$ gene at $68 \mathrm{E}(\mathrm{H}$. Vaessin and E. Giniger, in prep.). Expression of lacZ in these lines at mid-stages of embryogenesis is primarily in neurons, as is cyclin $A$ RNA and protein (Lehner and O'Farrell 1989; Whitfield et al. 1989; H. Vaessin and E. Giniger, pers. comm.). At earlier stages, cyclin $A$ may be derived primarily from maternal transcripts and shows a great degree of post-transcriptional regulation (Lehner and O'Farrell 1989), making it difficult to compare the cyclin $A$ protein level with the $l a c Z$ patterns. The patterns of cyclin $A$ RNA expression revealed by in situ hybridization in whole-mount embryos, however, show a good match with the lacZ expression (H. Vaessin and E. Giniger, in prep.). Thus, the lac $Z$ expression in these transformants appears to be similar to that of zygotically expressed cyclin $A$. The lac $Z$ fusion genes in both lines are transcribed in a direction opposite to that of the cyclin $A$ gene. Therefore, the cyclin $A$ regulatory sequences must be able to act in reverse orientation.

A P-lacW insertion also was found $<40$ bp from genomic sequences corresponding to the $5^{\prime}$ end of an apparently full-length cDNA from the rhomboid locus at 62A. The lac Z fusion gene in this P-lacW insertion is in reverse orientation to that of the endogenous transcript. The lac $Z$ pattern in this line has most features of the complex expression pattern revealed by in situ hybridization with this CDNA in whole mounts of postblastoderm embryos (E. Bier et al., in prep.).

An insertion into the vasa locus at $35 \mathrm{BC}$ was identified on the basis of lac $Z$ expression in pole cells. The zygotic expression of vasa in pole cells during embryogenesis and in spermatagonial stem cells in male flies is similar to the lac Z expression pattern in this line (Hay et al. 1988; B. Hay, pers. comm.).

Finally, two transformants have been discovered that show lac $Z$ expression patterns in imaginal discs very similar to those known for engrailed (en) and wingless 


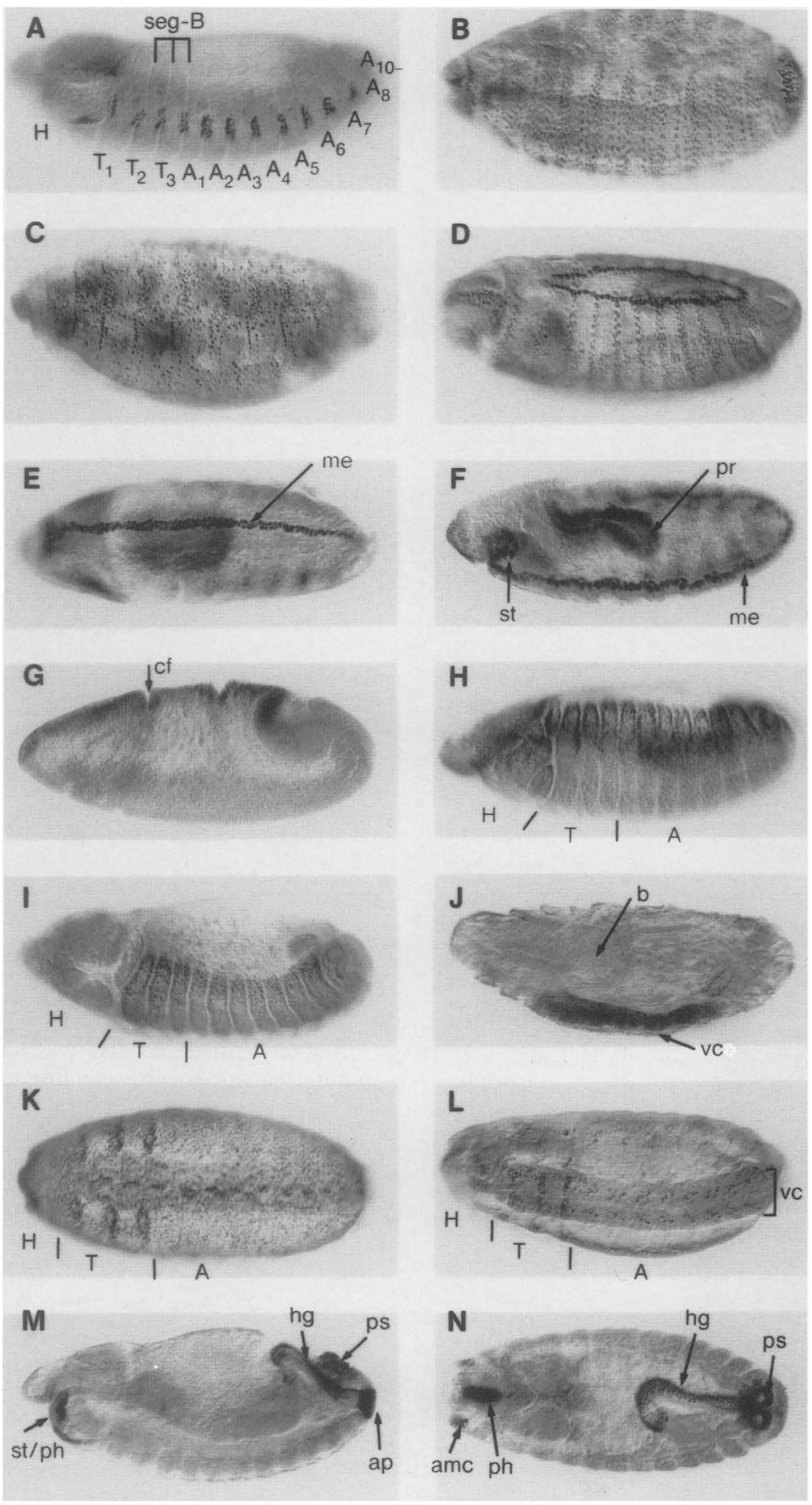

Figure 3. (See following page for legend.) 
Bier et al.

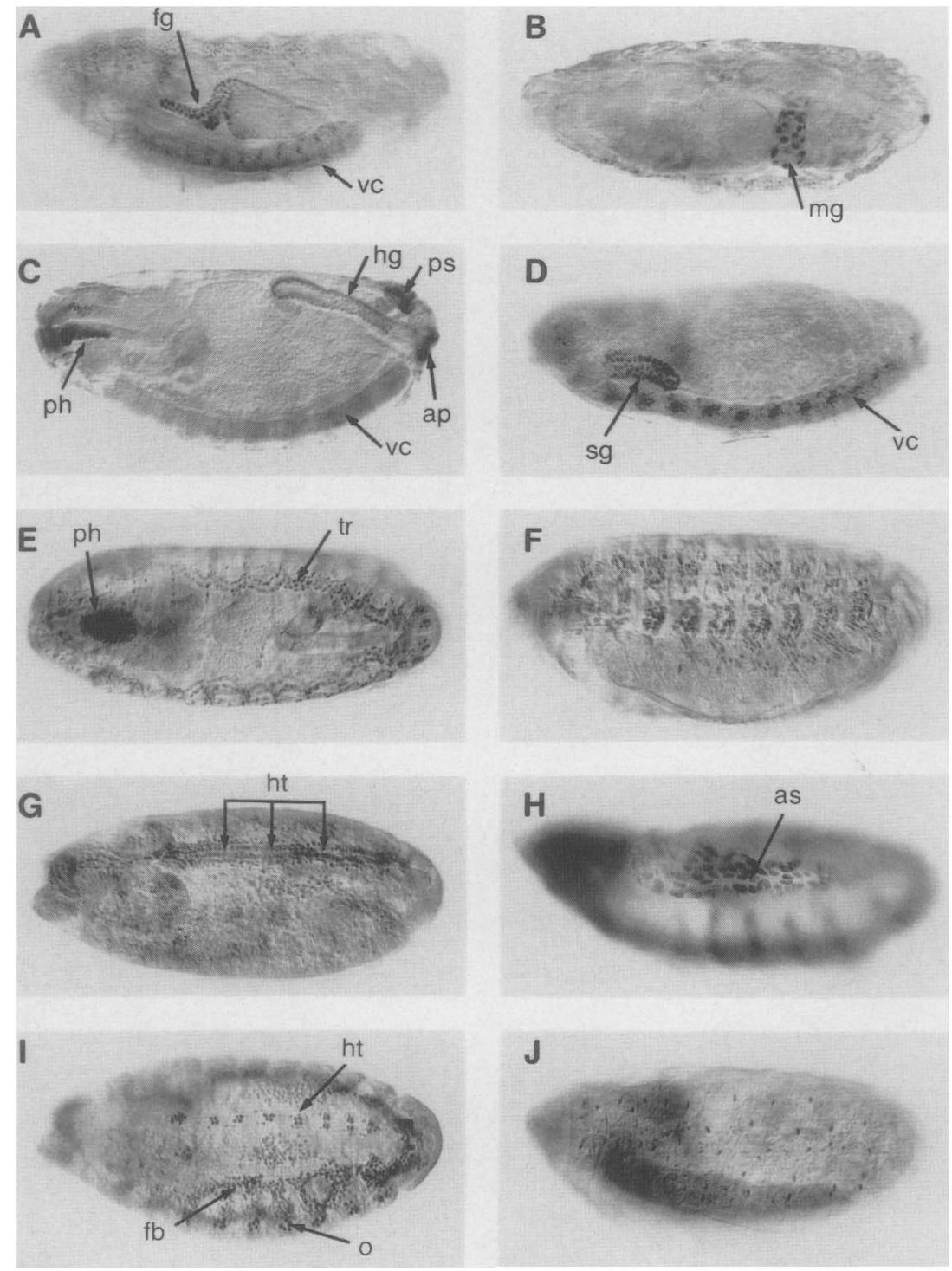

Figure 4. Tissue-specific patterning. The lacZ expression in different lines marks $(A)$ foregut $(\mathrm{fg}),(B)$ midgut $(\mathrm{mg}),(C)$ hindgut $(\mathrm{hg}),(D)$ salivary gland (sg) and a subset of cells in the CNS, $(E)$ pharynx $(\mathrm{ph})$ and subset of tracheal cells $\langle\operatorname{tr}),(F)$ muscle, $(G)$ heart $(\mathrm{ht}),(H)$ amnioserosa (as), $(I)$ fat body (fb), oenocytes $\{0\}$, and subset of heart cells, $(J)$ glia (see legend to Fig. 3 for other abbreviations). The lines are: A5 $3^{\text {rd }} 42(69 \mathrm{D})(A), \mathrm{E} 92^{\text {nd }} 10(B), \mathrm{A} 13^{\text {rd }} 10(C), \mathrm{B} 123^{\text {rd }} 5(D), \mathrm{B} 43^{\text {rd }} 31(E), \mathrm{B} 63^{\text {rd }} 23(F), \mathrm{E} 73^{\text {rd }} 63(G), \mathrm{E} 12^{\text {nd }} 3(H), \mathrm{E} 23^{\text {rd }} 9(I)$, and E8 $3^{\text {rd }} 57$ $(\eta)$.

Figure 3. Position-dependent lacZ patterns. Embryos of different lines stained with anti- $\beta$-galactosidase antibodies are shown with the anterior end to the left and the ventral side down. $(A-D)$ Segmentally repeated patterns; $(E$ and $F)$ ventral midline viewed from ventral $(E)$ and lateral $(F)$ perspectives; $(G$ and $H)$ exclusive expression in dorsal tissue during early gastrulation $(G)$ and during midembryogenesis $(H) ;(I$ and $I)$ ectodermal $(I)$ and CNS $(I)$ expression in abdominal and thoracic segments but not in head; $(K$ and $L)$ ectodermal $\langle K\rangle$ and CNS $(L)$ labeling with a different pattern in thoracic than in abdominal segments; $(M$ and $N)$ terminal structures including hindgut (hg), anal plate (ap), posterior spiracles (ps), antennal maxillary complex (amc), and pharynx (ph), from a lateral ( $M$ ) and dorsal (N) perspective. (b) Brain; (cf) cephalic furrow; (me) mesectoderm; (pr) protodeum; (seg-B) segment boundary; (st) stomodeal invagination; $(\mathrm{vc})$ ventral cord; $(\mathrm{A})$ abdomen; $(\mathrm{H})$ head; $(\mathrm{T})$ thorax. The designations for the lines are (the cytogical location of the insert when known follows the line number in parentheses): A6 $2^{\text {nd }} 45(A), \mathrm{A} 43^{\text {rd } 21}(B), \mathrm{B} 43^{\text {rd }} 20(97 \mathrm{CD})(D-F), \mathrm{E} 43^{\text {rd }} 49(G$ and $H), \mathrm{B} 4$ $2^{\text {nd }} 12(I$ and $H)$, B9 $3^{\text {rd }} 40(K)$ B4 $3^{\text {rd }} 20(L), A 33^{\text {rd }} 47(M$ and $N)$. (2nd and 3rd indicate the chromosome that harbors P-lacW.) 


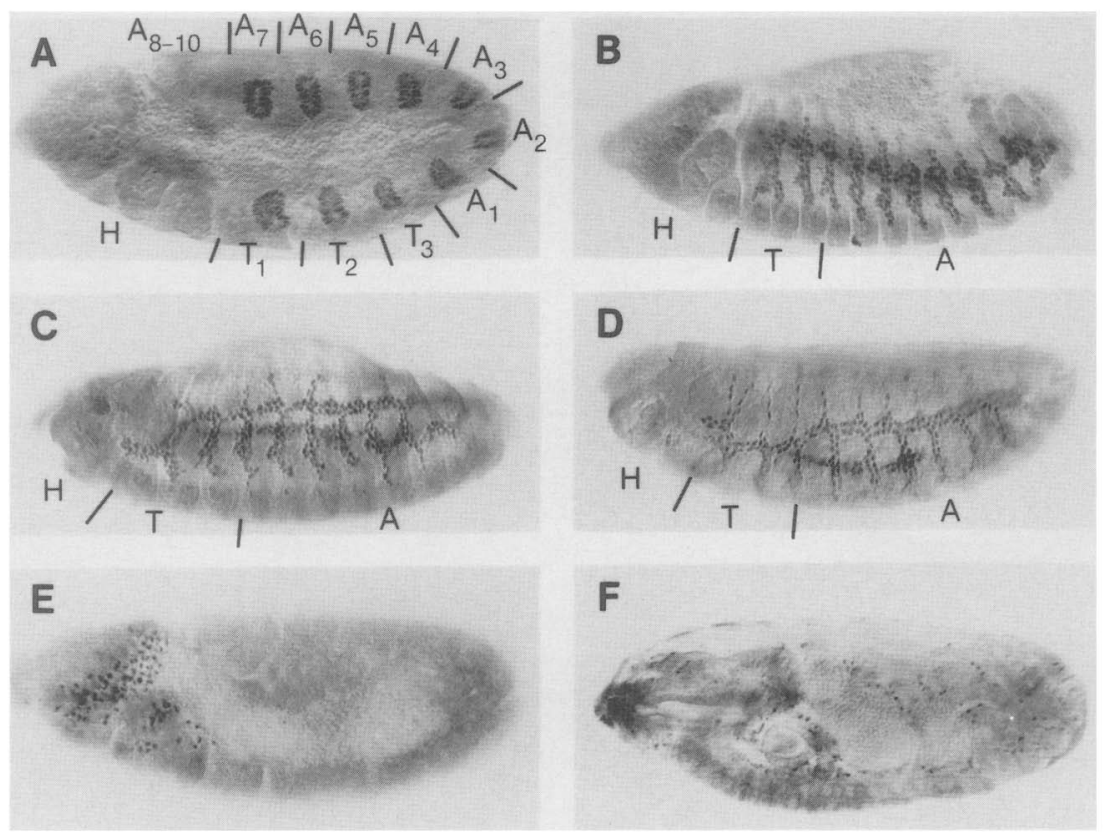

Figure 5. Developmental profiles revealed by lac $Z$ expression. $(A-D)$ Tracheal development. Tracheal pits form at 6-7 hr $(A)$. The tracheal cells move backward and elongate $|B|$, and then fuse at $\sim 10 \mathrm{hr}(C)$. These cells eventually form an intricate meshwork, with major tracks running longitudinally and fine processes running along the dorsoventral axis $(D)$. $(E-F)$ Ontogeny of a migratory cell type. The cells are located mostly in the anterior portion of the embryo initially $(5.5-7.5 \mathrm{hr}$.; $E)$ and then disperse as development proceeds $(14 \mathrm{hr} ; F)$. The line in $A-D$ is $6-81$ a $(70 \mathrm{D})$; the line in $E$ and $F$ is $5-45$ allI.

$(w g)$, respectively $\{\mathrm{S}$. Eaton, pers. comm.). The former also shows embryonic lacZ expression consistent with en expression. In these two lines, the P-lacW insertions were localized by in situ hybridization to the cytological positions of $e n(48 \mathrm{~A})$ and $w g(28 \mathrm{~A})$, respectively (Kuner et al. 1985; Baker 1987; S. Eaton, pers. comm.). Therefore, they most likely represent cases where the lac $Z$ expression patterns reflect the pattern of expression of genes near the insertion sites.

A number of lines that are embryonic lethal have PlacW insertions into genes for which the expression patterns have not been described yet (e.g., neuralized). Future comparison between expression patterns of such genes and the lac $Z$ patterns will provide further tests of this 'pattern-search' method. For the moment, we note that those P-lacW insertions that have been mapped to one locus tend to show similar lacZ patterns. Moreover, for those insertions into known loci, the tissues that express $l a c Z$ include those affected by the respective mutations.

\section{Embryonic mutant phenotypes identified among the lethal lines}

Table 2 summarizes the embryonic phenotypes observed among homozygous mutant embryos stained with anti-HRP. Of the 480 lethal lines examined, 68 , or $\sim 14 \%(\sim 2 \%$ of the total number of lines), showed some classifiable defect in the anti-HRP staining pattern.

Neurogenic mutants have been found at a rather high frequency. In screening the P-element-induced lethal mutations, probably only $5-10 \%$ of all lethal mutations have been sampled in the Drosophila genome, yet a total of 10 insertions in three of the five known autosomal neurogenic loci have been found plus an insertion in a new neurogenic locus. This is far greater than would be expected if there were no bias in the sites of P-lacW insertion.

Among the lines with $l a c Z$ staining, $12 \%$ are recessive lethal mutations. This figure is approximately the same as the frequency of lethal mutations among those with no or low level of staining (14\%). Thus, lacZ expression and lethality appear to be independent variables.

\section{Cytological hot spots among mapped P-lacW insertions}

P-lac W insertions were localized by in situ hybridization to polytene chromosomes for 119 lines that showed an interesting $l a c Z$ expression pattern or embryonic mutant phenotype. These insertions mapped to 73 distinct chromosomal locations, of which 55 are represented by single insertions, 11 by two independent insertions, and 7 by three or more insertions. Examples of hot spots for P-lacW insertions are three chromosomal locations with 10 or more insertions at each, which give rise to the 'all neurons' or 'all PNS' lacZ expression pattern (see Table 3 ). Of the 11 insertions at $47 \mathrm{~A}, 6$ are lethal and allelic. Three of these insertions map to a region of $\sim 100 \mathrm{bp}$ but do not occur at identical locations. Also, four master mind and five neuralized alleles have been recovered. Insertions at a given hot spot were derived from a mix of different $\mathrm{X}$ chromosome jumping lines with no apparent starting point bias. 
Bier et al.

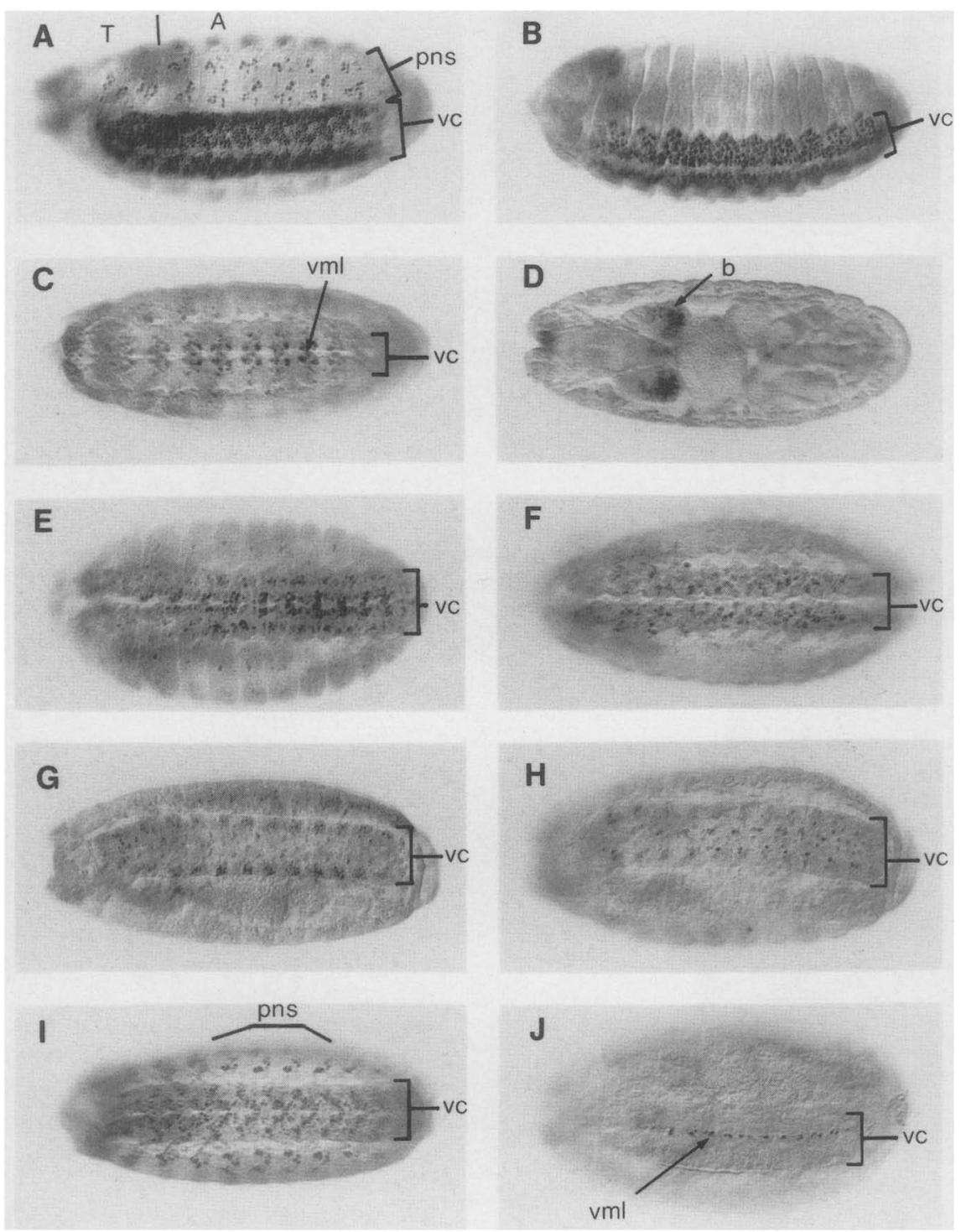

Figure 6. Neuronal staining lines. The different lines express lacZ in all known neurons in CNS and PNS $(A \mid, \mathrm{CNS}$ only $|B|$, glia $|C|$, the posterior portion of the brain $(D)$, or in subsets of cells in CNS $(E-I)$. (pns) Peripheral nervous system; (vml) ventral midline (see legend to Fig. 3 for other abbreviations $)$. The lines are: E7 $3^{\text {rd }} 44(64 \mathrm{~A})(A), \mathrm{E} 63^{\text {rd }} l(B), \mathrm{A} 23^{\text {rd }} 18(69 \mathrm{~B})(C), 5-100 \mathrm{~d}(101 \mathrm{~F})(D), \mathrm{E} 83^{\text {rd }} 29(E)$, $\left.\mathrm{B} 13^{\text {rd } 53}(F), 6-116 \mathrm{a} \mid G\right), \mathrm{B} 132^{\text {nd }} 3(53 \mathrm{~A})(H), \mathrm{C} 23^{\text {rd }} 33(94 \mathrm{D})(I)$, and $\mathrm{C} 82^{\text {nd }} 17(52 \mathrm{BD})(J)$.

\section{Discussion}

\section{lacZ expression patterns}

Iac $Z$ expression patterns have been examined in embryos of the 3768 independent P-lacW insertion lines. On the basis of genetic segregation and limited data on the chromosomal locations of the P-lacW insertions, $-90 \%$ of these lines contain only a single P element. The richness of pattern in this collection is the most obvious feature of the data presented. At least $64 \%$ of the lines show some lacZ staining, and most of those lines express $l a c Z$ in a nonubiquitous pattern. In most cases where particular embryonic tissues express $l a c Z$, the same tissues are labeled throughout embryonic development.

A prominent feature in Table 1 is the high frequency of lines with lacZ expression in the nervous system or gut $(49 \%$ and $15 \%$ of the staining lines, respectively). Often this lacZ expression is found in different subsets of cells. In vertebrates, these tissues are known to consist of many different cell types. The differential expression of lac $Z$ in subsets of cells indicates that the nervous system and gut in Drosophila also contain a number of different kinds of cells. Thus, the high frequency of lines with lacZ expression in the nervous system or gut may simply reflect the much greater complexity of cell types in these tissues.

Because multiple hits have been seen for many loci (Table 3), the number of loci sampled is fewer than the total number of lines. The 119 insertions analyzed were localized to 73 different chromosomal sites. If values from this preselected set are representative, the 3768 

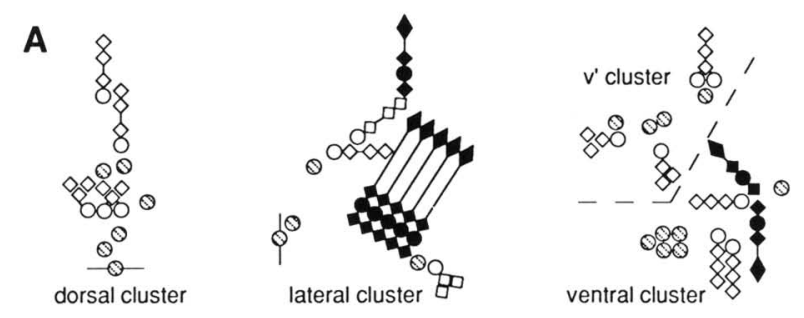

$$
\begin{aligned}
& \diamond \text { neuron } \\
& \diamond \text { support cell } \\
& \diamond \text { md cell } \\
& \text { ch organ } \\
& \diamond \text { es organ }
\end{aligned}
$$
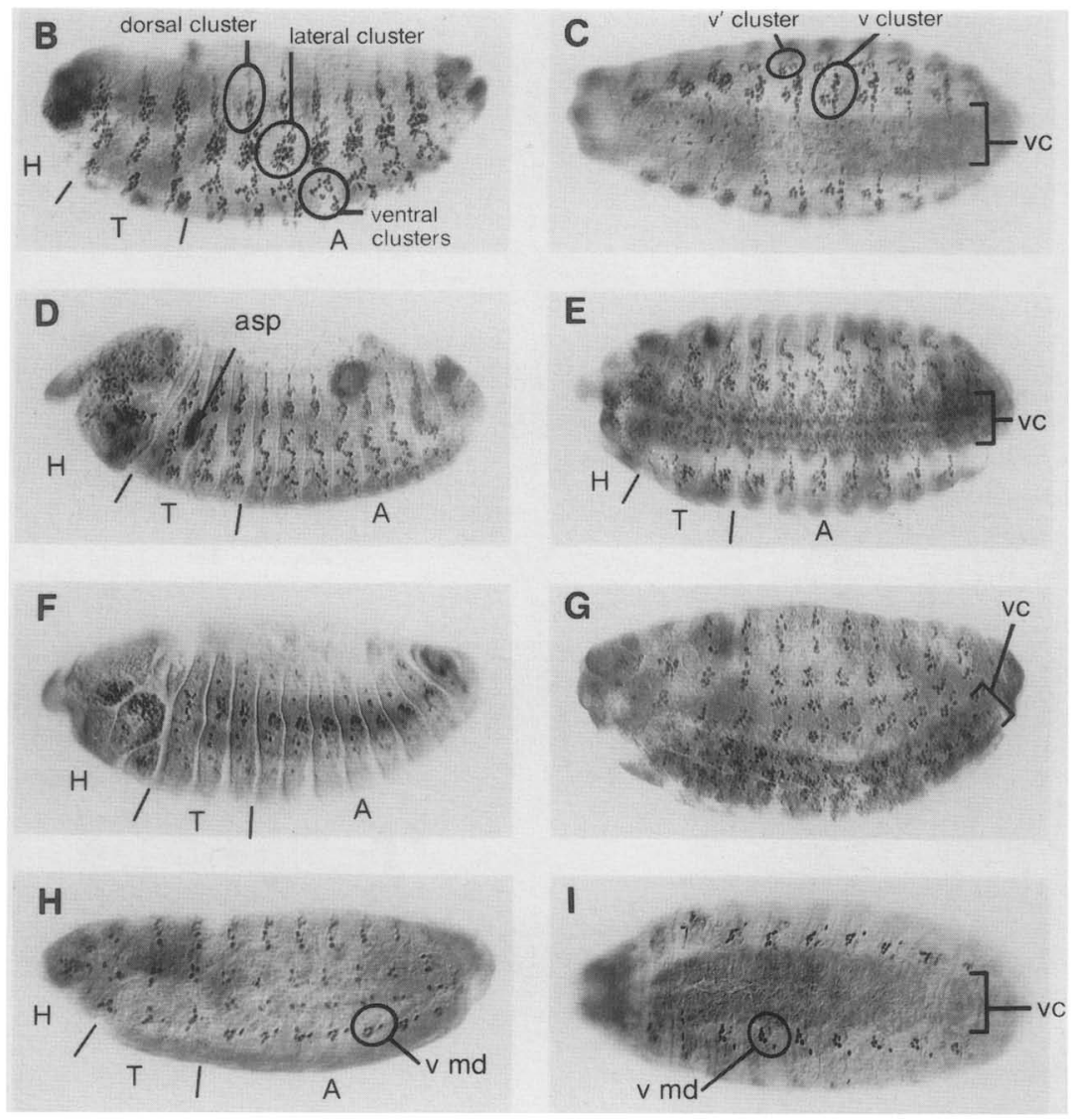

Figure 7. PNS marker lines. $(A)$ Diagram of PNS. Cells in the three major PNS clusters are portrayed. Neurons are represented by circles and support cells by diamonds. The different shadings denote the three major cell types in the PNS: solid symbols for chordotonal (ch) organ (stretch receptor) cells, open symbols for external sensory (es) organs, and hatched symbols representing neurons with multiple dendrites (md) (possibly touch receptors). ( $B$ and $C \mid$ All of the cells in the PNS, including neurons and support cells, label. A lateral view $(B)$ includes three major clusters in each hemisegment: a dorsal cluster, a lateral cluster and two overlapping ventral $\mid \mathrm{v}$ and $\left.\mathrm{v}^{\prime}\right)$ clusters. A ventral view $(C)$ shows position of the ventral neurons in the PNS relative to that of the CNS. $(D$ and $E)$ External sensory organ cells are labeled by the anti-cut antibody (Blochlinger et al. 1988). Both neurons and support cells of external sensory organs are labeled. Lateral $(D)$ and ventral $(E)$ aspects are featured. $|F|$ A transformant line in which a subset of external sensory cells are labeled. (G) Another line in which PNS cells derived from the anterior compartment, as well as a subset of cells in the CNS, express $l a c Z$. ( $H$ and $I$ ) Only multiple dendrite cells in the PNS are stained in this line; there is no CNS labeling. Note the differences between abdominal and thoracic patterns in each case. (asp) Anterior spiracle. The lines are: $1(3)$ 5D4 $(90 D, E)(B$ and $C)$, wild-type embryos stained with anti-cut antibody $(D$ and $E)$, B8 $3^{\text {rd } 41}\langle F\rangle, \mathrm{A} 33^{\text {rd }} 73(94 \mathrm{D})(G)$, and $\mathrm{E} 62^{\text {nd }} 11(31 \mathrm{E}, \mathrm{F})(H$ and $I)$.

lines generated would correspond to $\sim 2300$ different chromosomal sites. On the average, these insertions would be $\sim 50-100 \mathrm{~kb}$ apart, assuming P-element insertions are random on a chromosomal scale (Spradling 1986). Although this is certainly not saturating the genome for patterning, it represents a significant sampling.
One question of obvious interest is whether the lac $Z$ patterns reflect the true expression patterns of neighboring genes. A number of cases exist in which the lacZ patterns are similar or identical to the expression patterns of genes at the sites of P-lacW insertion (i.e., insertions at elav, cyclin $A$, rhomboid, vasa, en, and $w g$ ). The insertions characterized at a molecular level so far 


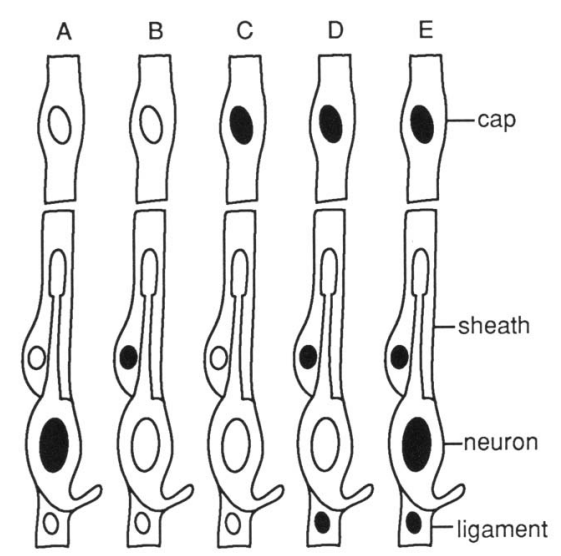

Figure 8. Diagram of chordotonal organ markers. A chordotonal organ is comprised of a neuron, a sheath cell, which wraps the neuronal dendrite, and two attachment cells, the ligament cell and the cap cell. $(A-E)$ Diagrams of chordotonal cells that label in different transformants. These different lines express $l a c Z$ in the neuron only $(A)$, the sheath cell only $(B)$, the cap cell only $(C)$, the three support cells but not the neuron $(D)$, or in all four chordotonal cells $(E)$. Lines showing these lacZ patterns are E7 $3^{\text {rd }} 44(64 \mathrm{~A})(A), \mathrm{A} 62 \mathrm{nd} 33(B), \mathrm{E} 72^{\text {nd }} 7(47 \mathrm{~A})(C), \mathrm{B} 13^{\text {rd } 51}$ (100D) $(D)$, and $1(3) 5 \mathrm{D} 4(90 \mathrm{D}, \mathrm{E})(E)$.

have the P-lacW inserted within $500 \mathrm{bp}$ of the endogenous genes. To obtain a crude estimate of the proportion of patterns that accurately reflect the endogenous gene expression patterns, genes are being characterized in the vicinity of those insertions that give rise to specific patterns in the nervous system.

\section{Potential uses of P-lacW lines}

The great variety of $1 a c Z$ patterns found in different lines can be used as cell-type or position-dependent markers for analysis of development. The line that marks trachea (see Fig. 5A-D) is a good example of how complex developmental events can be followed with the aid of a clean marker. In the Drosophila PNS, all cells have been identified (Hertweck 1931; Campos-Ortega and Hartenstein 1985; Ghysen et al. 1986; Bodmer and
Jan 1987; Hartenstein 1988; Bodmer et al. 1989); thus, the PNS represents a test case for how effective our PlacW screen has been in generating cell-type-specific markers. Lines have been obtained now that permit independent labeling of virtually every cell type in the PNS, for example, lines staining type II neurons (multiple dendrite neurons), subsets of chordotonal stretch receptor cells, and subsets of external sensory organ cells. These different lines are not only useful for analysis of mutants, but also provide information on the normal genesis of these cell types (e.g., Uemura et al. 1989|. In the CNS, which is far more complicated than the PNS, the variety of lines marking subsets of cells permits one to follow limited subpopulations of neurons or glial cells. These glial cells are believed to play a pivotal role in early CNS development (Bastiani and Goodman 1986; Jacobs and Goodman 1989; Jacobs et al. 1989|. The lacZ-expressing lines also are useful as markers for other embryonic tissues (e.g., Figs. 3 and 4) and at other stages of development.

Potentially, these P-lacW lines may lead to identification of genes with expression patterns similar to the lac $Z$ patterns. The P-lacW element described in this report combines the advantages of a number of previously existing vectors (O'Kane and Gehring 1987; Cooley et al. 1988; Pirrotta 1988). The plasmid sequences in P-lacW allow one to clone DNA-flanking insertions in both the $5^{\prime}$ and $3^{\prime}$ directions. If a significant fraction of the lacZ patterns reflect the expression pattern of nearby genes, this approach could be of particular value for identifying and isolating three classes of genes. One might identify genes that are regulated at the transcriptional level by known genes of interest. For example, the bithorax complex plays a role in determining the identity of cells in the thorax and in the abdomen (Lewis 1978; Bender et al. 1983; Karch et al. 1985), whereas the cut locus is expressed in all external sensory organs and specifies their identity (Bodmer et al. 1987; Blochlinger et al. 1988). If genes were associated with the patterns of $l a c Z$ expression seen in Figure 3, I-L, or Figure 7F, they could be candidate downstream genes for the bithorax complex or the cut locus, respectively. The pattern-hunting approach might also uncover genes that are required for
Figure 9. A P-lacW insertion in the elav gene promoter. $(A)$ Genomic map of elav indicating the site of $\mathrm{P}-\mathrm{lacW}$ insertion and the region giving rise to the various elav transcripts (Robinow et al. 1988). The insert lies $\sim 100$ bp upstream of the transcription start site for at least one elav RNA (S. Robinow, pers. comm.). (B) Staining pattern of this insertion line (5-45fD). All known neurons in the embryo express lacZ. (C) Antibody staining pattern of the monoclonal antibody $\mathrm{mAb} 44 \mathrm{Cl1}$, which recognizes the gene product of the elav locus (Bier et al. 1988; Robinow et al. 1988). Symbols for restriction enzymes are as in Fig. 1.
A
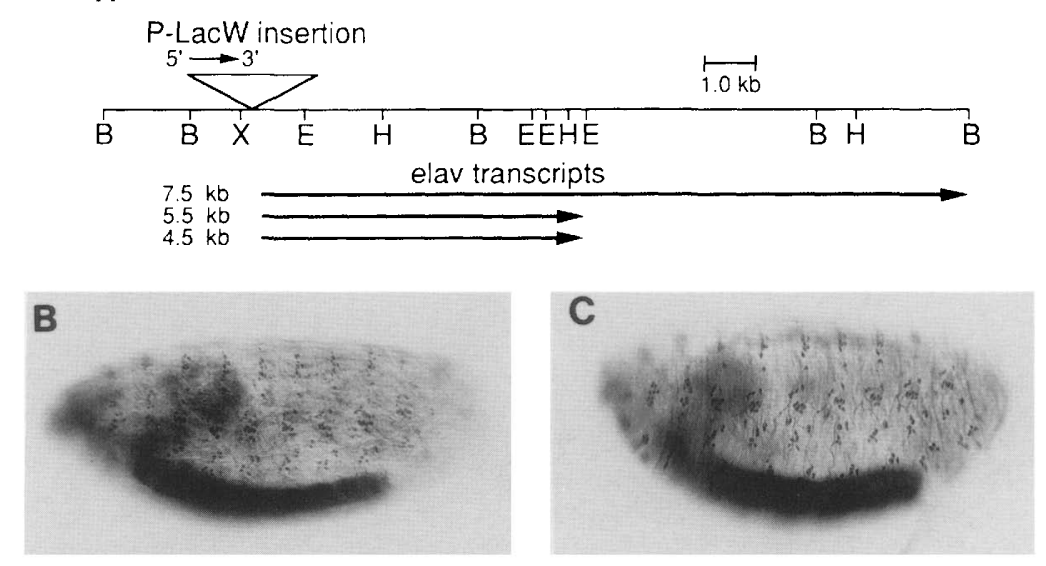
Table 2. Lethal mutations

\begin{tabular}{|c|c|c|c|}
\hline Embryonic phenotype & Sites & Known loci & insertions \\
\hline \multirow[t]{4}{*}{ Neurogenic } & $24 \mathrm{D}$ & new locus & 1 \\
\hline & $50 \mathrm{C}, \mathrm{D}$ & master mind & 4 \\
\hline & $85 \mathrm{C}$ & neuralized & 5 \\
\hline & $92 \mathrm{~A}$ & Delta & 1 \\
\hline \multirow[t]{4}{*}{ CNS abnormal } & $47 \mathrm{~A}$ & new locus & 6 \\
\hline & $48 \mathrm{E}$ & ND & 1 \\
\hline & $53 \mathrm{~A}$ & ND & 2 \\
\hline & ND & ND & 3 \\
\hline Axon misrouting & ND & ND & 4 \\
\hline PNS neurogenic & $100 \mathrm{D}$ & new locus & 1 \\
\hline \multirow[t]{4}{*}{$\mathrm{CHO}$ missing or reduced } & $37 \mathrm{E}$ & spitz & 1 \\
\hline & $62 \mathrm{~A}$ & rhomboid & 1 \\
\hline & $84 \mathrm{BC}$ & ND & 1 \\
\hline & $101-102$ & ND & 1 \\
\hline Segmental defects & ND & ND & 17 \\
\hline Gastrulation defects & ND & ND & 5 \\
\hline \multirow[t]{2}{*}{ Cell-cycle defects } & $68 \mathrm{E}$ & $\operatorname{cyclin} A$ & 2 \\
\hline & $99 \mathrm{~A}$ & string & 2 \\
\hline Miscellaneous & ND & ND & 10 \\
\hline Total & & & 68 \\
\hline
\end{tabular}

The embryonic phenotypes, with respect to anti-HRP staining, chromosomal locations of P-lacW insertion (sites), number of independent insertions (insertions), and correspondence to known loci (as determined by complementation tests) are listed. Unless noted, lines within a given group have not been tested for allelism. (CHO) Chordotonal organs; (ND) not determined; (new locus) not corresponding to any known loci of similar phenotype.

normal development but do not give an obvious morphological defect when mutated. One such example is the elav gene, which is expressed early in all neurons (Fig. 9), is embryonic lethal, and may provide important functions for neuronal development (Campos et al. 1987; Robinow and White 1988|. The elav embryonic phenotype, however, is subtle and would have been missed by screens such as anti-HRP labeling of the nervous system. Characterization of genes of a particular temporal and spatial pattern of expression might also reveal genes that provide redundant functions. Thus far, such genes have been found only when multiple genes providing the redundant functions are deleted at the same time, for example, the segment polarity locus gooseberry (Bopp et al. 1986; Baumgartner et al. 1987) and the neurogenic locus Enhancer of split (Ziemer et al. 1988). Finally, it may be possible to identify genes that play important roles at multiple developmental stages. Such genes would be difficult to identify in classical mutant screens because the later phenotypes could be obscured by earlier defects.

Although there are many promising facets to the pattern-hunting approach of identifying new genes, a few limitations of this method should be mentioned. Obviously, this method will be of use only if a reasonable fraction of patterns is found to be associated with the expression patterns of endogenous genes. Not enough information is available at the moment to provide an estimate for the proportion of patterns indicative of endogenous gene activity. Of those lac $Z$ patterns associated with genes, a few caveats should be considered. For instance, based on expression pattern, one could easily miss those genes that are expressed relatively ubiquitously but play important developmental roles in specific regions or cell types. The Notch gene is an example of this kind. Notch plays an important role in allowing cells in the ventrolateral region of the embryo to make the choice between assuming epidermal or neuronal fate (Lehmann et al. 1983). The expression of Notch, however, is in cells in the dorsal, as well as ventral, regions during this period of embryogenesis (Hartley et al. 1987). One might also have difficulty in identifying genes with very dynamic patterns of expression, for example, the string locus (Edgar and O'Farrell 1989), because the lacZ fusion product is relatively stable and would tend to integrate the changing expression pattern, leaving an impression of ubiquitous expression. Finally, it is important to state that interesting expression patterns may not be indicative of the true domains of genetic function. For instance, although many photoreceptor cells in addition to the $\mathrm{R} 7$ photoreceptors express sevenless even after their determination (Baneriee et al. 1987; Tomlinson et al. 1987), mosaic studies have shown that sevenless function is only required in the $\mathrm{R} 7$ photore-

Table 3. Hot spots among mapped P-lacW insertions

\begin{tabular}{lcccc}
\hline Locus & $\begin{array}{c}\text { Known } \\
\text { alleles }\end{array}$ & $\begin{array}{c}\text { Number of } \\
\text { lethal insertions }\end{array}$ & Staining pattern & $\begin{array}{c}\text { Number of } \\
\text { lacZ-expressing } \\
\text { lines }\end{array}$ \\
\hline 35D,E & - & 0 & complex, early & 3 \\
47A & - & 6 & all neurons & 11 \\
49D & - & 0 & all neurons & 10 \\
50C,D & master mind & 4 & CNS & 4 \\
85C & neuralized & 5 & most embryonic cells & 5 \\
90D,E & - & 9 & all PNS cells & 10 \\
94D & - & 0 & Subset of cells & in the PNS \\
\end{tabular}

Hot spots are defined as loci with three or more inserts at the same cytological location which, in addition, share some phenotype (e.g., lacZ staining pattern or embryonic phenotype revealed by anti-HRP staining). This by no means defines the majority of P-lacW hot spots because no systematic mapping of insertions has been done; rather, these data roughly reflect the occurrence of hot spots relative to single insertions in a limited group sharing some common properties. 
ceptor cells (Harris et al. 1976; Campos-Ortega et al. 1979; Tomlinson and Ready 1987).

The fact that P-lacW carries the dominant mini-white marker permits a variety of genetic manipulations. One classical application is the isolation of small deletions that have lost the dominant marker. This can be accomplished by screening for loss of the mini-white marker following either remobilization of the element with transposase, which may cause imprecise excision, or by treating with $\mathrm{X}$ rays to generate larger deletions. In addition, because the mini-white gene is cell autonomous, one may generate somatic mosaics in the eye such that patches of tissue are homozygous for a lethal P-lacW insertion (which can be distinguished from heterozygous tissue by color). Knowledge of the adult eye phenotype of lethal mutations may facilitate analysis of genes that participate in neuronal development.

\section{Evolutionary implications of the high frequency of patterning}

Most P-lacW insertions analyzed cause nonubiquitous lacZ expression. Moreover, the intensity of expression of the mini-white gene in the eye depends to a high degree on the chromosomal location of the insertion. These observations suggest that there is a high density of patterning information in the genome. This richness of pattern may play an important role during evolution. When chromosomal breakage arises due to deletion, duplication, inversion, translocation, or transposon activity, genes in the vicinity of these breaks may often experience alterations in their pattern of expression. For instance, in the Antennapedia ${ }^{73 B}$ mutant, a chromosomal rearrangement leads to ectopic Antennapedia gene expression; as a consequence, the antennae are transformed into legs (Schneuwly et al. 1987a,b). It is easy to imagine that more advantageous situations than that illustrated by the Antennapedia mutation may occur, and that the high frequency of patterning elements in the genome might contribute to more rapid rates of evolution of promoter and/or enhancer activities. One consequence could be differential expression of recently duplicated genes.

It has been proposed that the protein-coding regions of genes in higher eukaryotes have retained the ancient property of being broken up by introns because the presence of introns permits separation of different functional protein domains that may be combined in different ways by exon shuffling to create new compound proteins (Gilbert 1978; Marchionni and Gilbert 1986). Other similar hypotheses have also been suggested (Blake 1978; Go $1981,1983)$. In view of the richness of patterning information in the fly genome, one might venture an additional explanation for the retention of the significant excess of noncoding versus coding DNA $\sim \sim 10: 1$ in Drosophila). Perhaps pattern shuffling has been a driving force to retain large domains of noncoding intergenic and intron sequences, which not only permits exon shuffling but pattern shuffling as well. One obvious difference between a simple eukaryote such as yeast and a multicel- lular organism such as a fly is that genes of the latter are expressed differentially and dynamically in many different cell types during development. Thus, pattern shuffling may have been a strong incentive to keep genes in parts and apart during the evolution of multicellular organisms.

\section{Methods}

Isolation of transformed flies with P-lacW inserted on the $X$ chromosome

P-lacW was introduced into the fly germ line by standard methods (Rubin and Spradling 1982). Approximately $3000 \mathrm{em}$ bryos were injected and 244 independent insertions were recovered in the genome, including 72 lines with P-lacW inserted into the $\mathrm{X}$ chromosome.

\section{Frequency of transposition}

The mobilization frequencies for the different P-lacW insertions were determined by $20-50$ individual crosses, each consisting of one male, carrying both P-lacW and transposase ( $\Delta 2-3)$, mated to white females. The progeny were scored for the presence of any red-eyed white $e^{+}\left(w^{+}\right)$males. (In the absence of transposition onto an autosome, all males should be white, because they receive their $\mathrm{X}$ chromosomes only from their mothers.) The proportion of matings that gave rise to at least one $W^{+}$male ranged between 50 and $100 \%$ for the five lines (Fig. 1B). In general, vials in which transposition had occurred contained one to five $w^{+}$males. Often the $w^{+}$males had the same intensity and quality of pigmentation, but sometimes two distinct color classes were observed. Insertions at different chromosomal locations often have different eye colors because mini-white expression is very sensitive to position effects (see Pirrotta 1988|. For the purposes of the screen, we considered all progeny within a vial with similar eye color to share a common P-lacW insertion and those with definite eye color differences to differ in at least one P-lacW insertion.

\section{Genetic mobilization scheme}

The basic genetic design involves crossing (en masse) males carrying transposase activity on the third chromosome, provided by the $\Delta 2-3 \mathrm{P}$ element, which is inserted at $99 \mathrm{~B}$ and apparently immobilized (Robertson et al. 1988), to white females that were homozygous for a P-lacW insertion on the $\mathrm{X}$ chromosome (and therefore had pigmented eyes). Males that carried $\mathrm{P}$-lacW on the $\mathrm{X}$ chromosome (maternally derived) and transposase on the third were recovered from this cross. The $\Delta 2.3$ transposase-producing chromosome was marked with the dominant Stubble bristle marker but could also be scored easily by the $\Delta 2.3$ transposase activity directly. Because the absence of the last intron in the $\Delta 2-3 \mathrm{P}$ element causes expression of transposase in all tissues, rather than exclusively in the germ line (Laski et al. 1986), flies that carry both P-lacW and $\Delta 2-3$ have eyes with patches of color mixed with white areas, a phenomenon known as somatic variegation (for review, see Engels 1988).

Approximately 4400 individual vials were set up, each with two P-lacW, $\Delta 2-3$ males crossed to three white females carrying the second chromosome balancer $\mathrm{CyO}$. Male progeny from such a cross will inherit the white $\mathrm{X}$ chromosome from their mothers and will have white eyes unless the $\mathrm{r}$-iacW in the father has jumped to an autosome, in which case, the P-lacW element could segregate into both male and female offspring, re- 
sulting in pigmented eyes. In 3768 vials $(86 \%)$, at least one $w^{+}$ male was recovered (i.e., a P-lacW transposition to an autosome). The range of eye colors as a result of position effect in these transformed flies varied form very light yellow to essentially wild-type red, with the bulk of insertions yielding an intermediate orange shade. The transformed males $\mid \mathrm{CyO}$ and without the $\Delta 2-3$ chromosome/ were crossed individually to $\mathrm{w}^{-}$ $\mathrm{CyO}$ females. Their male and female progeny, which had P-lacW and CyO but lacked $\Delta 2-3$, were scored to determine whether the insertion was on the second or the third chromosome (see Fig. 2). Five to ten of these males and females were placed in a vial, and progeny of these flies then were examined for the presence of individuals homozygous for the P-lacW insertion. For P-lacW insertions on the second chromosome, $\mathrm{Cy}^{+}$ flies (i.e., homozygous for P-lacW) had darker eyes (usually dull red) than $\mathrm{CyO}$ flies (i.e., heterozygous for P-lacW). This good agreement allowed us to score with confidence the third chromosome insertion lines by the eye color criteria alone. Using appropriate second or third chromosome balancers, 530 lethal lines were identified and balanced. Subsequently, embryos were collected from balanced lethal lines and stained with anti-HRP. Lines that gave reproducible anti-HRP phenotypes in onequarter of the embryos were selected for further analysis.

\section{Fly stocks}

All genetic markers used for the jumping scheme are described in Lindsley and Grell (1968). The null white allele (w67C23) was obtained from V. Pirrotta. The $\Delta 2-3$ stock was obtained from W. Engels. All possible second and third chromosome targets for P-lacW were isogenized with double or triple balancers just prior to the screen to remove background lethal mutations. These stocks, as well as the $\mathrm{X}$ chromosome $\mathrm{P}-\mathrm{lacW}$ insertion line 3-76a (line A in Fig. 1B), are available at the Bloomingon Stock Center.

\section{Screening for lacZ expression}

Several adaptations of standard protocols were used to facilitate screening the large number of lines described here. The large quantity of food required for this study was prepared with a new semiautomatic system (Cyberlab, Inc., Cyberlab C-100). Details of the procedure will be published elsewhere (S. Barbel and L. Ackerman, in prep.). Briefly, female flies (25 or more) and male flies were collected from each insertion line and placed in food vials with heavy yeast paste. After 2 days at $25^{\circ} \mathrm{C}$ with a 12-hr light/dark cycle, the flies were transferred to vials containing microscope slide coverslips coated with grape agar and a thin yeast paste. Embryos were collected overnight then washed into sample wells with $0.7 \% \mathrm{NaCl}, 0.1 \%$ Triton $\mathrm{X}-100$ ( $\mathrm{NaCl} /$ Triton).

\section{Mass preparation of embryos with X-Gal}

Embryos washed into custom-made 26-well baskets were dechorionated with bleach, rinsed in $\mathrm{NaCl} /$ Triton, fixed for 30 min in $5 \%$ formaldehyde in $0.1 \mathrm{M}$ sodium phosphate $(\mathrm{pH} 7.2)$ mixed with an equal volume of heptane, rinsed in $\mathrm{NaCl} /$ Triton, and incubated in an X-Gal solution (Hiromi et al. 1985) overnight at room temperature in the dark with gentle shaking. The samples were placed in water, $0.1 \mathrm{M}$ sodium phosphate, or $\mathrm{NaCl} /$ Triton for examination with a stereomicroscope.

\section{Anti- $\beta$-galactosidase staining of embryos}

The embryos were dechorionated with bleach $15.25 \%$ sodium hypochlorite), rinsed with $\mathrm{NaCl} /$ Triton, and fixed with equal volumes of $4 \%$ formaldehyde in $0.1 \mathrm{M}$ sodium phosphate $\langle\mathrm{pH}$ $7.2)$ and heptane. The embryos were devitellinized with equal volumes of $90 \%$ methanol and heptane, transferred to custommade racks and rehydrated with $0.1 \mathrm{M}$ sodium phosphate and $0.3 \%$ Triton X-100, and blocked with $2 \%$ bovine serum albumin and $3 \%$ normal goat serum. The antibody incubations and rinses were all in the buffer mentioned above. The rabbit anti- $\beta$-galactosidase (Cappel) was used at $1: 4000$, and the biotinylated goat anti-rabbit/Avidin D-horseradish peroxidase (Vector Laboratories, PK-4001), at $1: 200$. After reacting HRP with diaminobenzidine, the samples were dehydrated in ethanol, cleared in xylene, and mounted on slides with Permount (Fisher) for examination with a Nomarski optical microscope.

\section{Molecular techniques}

Plasmid rescue from minipreps of fly DNA was performed according to Pirrotta (1986). Other cloning techniques were performed by standard procedures as in Maniatis et al. (1982). In situ hybridizaiton to polytene chromosomes was done using the chromosome squash procedure of Gall and Pardue (1971) and a protocol of hybridization with biotinylated probes (Langer-Safer et al. 1982).

The first step in P-lacW construction was the joining of the lacZ gene bearing the HindIII fragment from pMP1108 (M. Peifer, unpubl.) with the P-element ends carried on the phs-Neo 2.6-kb BamHI-PvuII fragment (Steller 1984) to form P-lac1. This step produces an in-frame fusion of P-element transposase with $l a c Z$ (pTps-lacZ) at approximately the same location as that used in the vector of $\mathrm{O}^{\prime}$ Kane and Gehring (1987). The mini-white gene was moved from CaSpW18, which is the CaSpeR vector (Pirrotta 1988), with EcoRI sites flanking the mini-white gene, into pMT21 to yield p-white. In the final step, $\mathrm{p}$-white was inserted in place of pBR322 into P-lac1 to give PlacW.

\section{Acknowledgments}

We thank Drs. H. Steller, M. Peifer, and V. Pirrotta for providing DNA clones required for the construction of P-lacW; Drs. C. O'Kane and W. Bender for advice on P-lacW construction; Dr. V. Hartenstein for helpful discussions about the data and manuscript; and Ms. L. Schulte for help in preparing the manuscript. L.Y.J. and Y.N.J. are Howard Hughes Medical Institute investigators. H.V. is supported by the Deutsche Forschungsgemeinschaft.

\section{References}

Baker, N.E. 1987. Molecular cloning of sequences from wingless, a segment polarity gene in Drosophila: The spatial distribution of a transcript in embryos. EMBO I. 6: 1765-1773.

Banerjee, U., P. Renfranz, D. Rabin, and S. Benzer. 1987. The sevenless ${ }^{+}$is expressed apically in cell membranes of developing Drosophila retina; it is not restricted to cell R7. Cell 51: $151-158$.

Bastiani, M.J. and C.S. Goodman. 1986. Guidance of neuronal growth cones in the grasshopper embryo. III. Recognition of specific glial pathways. J. Neurosci. 6: 3542-3551.

Baumgartner, S., D. Bopp, M. Burri, and M. Noll. 1987. Structure of two genes at the gooseberry locus related to the paired gene and their spacial expression during Drosophila embryogenesis. Genes Dev. 1: 1247-1267.

Bender, W., M. Akam, F. Karch, P. Beachy, M. Peifer, P. Spierer, E.B. Lewis and D. Hogness. 1983. Molecular genetics of the bithorax complex in Drosophila melanogaster. Science 221: 23-29. 
Bingham, P., R. Levis, and G.M. Rubin. 1981. Cloning of DNA sequences from the white locus of Drosophila melanogaster by a novel and general method. Cell 25: 693-704.

Bier, E., L. Ackerman, S. Barbel, L.Y. Jan, and Y.N. Jan. 1988. Identification and characterization of a neuron-specific nuclear antigen in Drosophila. Science 240: 913-916.

Blake, C. 1978. Do genes-in-pieces imply proteins-in-pieces. Nature 273: 267-268.

Blochlinger, K., R. Bodmer, J. Jack, L.Y. Jan, and Y.N. Jan. 1988. Primary structure and expression of a product from cut, a locus involved in specifying sensory organ identity. Nature 333: 629-635.

Bodmer, R. and Y.N. Jan. 1987. Morphological differentiation of the embyronic peripheral neurons in Drosophila. Wilhelm Roux's Arch. Dev. Biol. 196: 69-77.

Bodmer, R., S. Barbel, S. Shepherd, I. Jack, L.Y. Jan, and Y.N. Jan. 1987. Transformation of sensory organs by mutations of the cut locus of D. melanogaster. Cell 51: 293-307.

Bodmer, R. R. Carretto, and Y.N. Jan. 1989. Neurogenesis of the peripheral nervous system in Drosophila melanogaster embryos: DNA replication patterns and cell lineages. Neuron 3: $21-32$

Bopp, D., M. Burri, S. Baumgartner, G. Frigerio, and M. Noll. 1986. Conservation of a large protein domain in the segmentation gene paired and in functionally related genes of Drosophila. Cell 47: 1033-1040.

Campos, A.R., D. Rosen, S. Robinow, and K. White. 1987. Molecular analysis of the locus elav in Drosophila melanogaster: A gene whose embryonic expression is neural specific. EMBO I. 6: 425-431.

Campos-Ortega, J. and V. Hartenstein. 1985. The embryonic development of Drosophila melanogaster. Springer-Verlag, New York.

Campos-Ortega, J.A., G. Jürgens, and A. Hofbauer. 1979. Cell clones and pattern formation: Studies on sevenless, a mutant of Drosophila melanogaster. Wilhelm Roux's Arch. Entwicklungsmech. Org. 186: 27-50.

Cooley, L., R. Kelley, and A. Spradling. 1988. Insertion mutagenesis of the Drosophila genome with single P-elements. Science 239: 1121-1128.

Edgar, B.A. and P.H. O'Farrell. 1989. Genetic control of cell division patterns in the Drosophila embryo. Cell 57: 177-187.

Engels, W. 1988. P-element in Drosophila. In Mobile DNA led. D. Berg and M. Howe), American Society for Microbiology, Washington, D.C. (in press).

Gall, J.G. and M.L. Pardue. 1971. Nucleic acid hybridization in cytological preparations. Methods Enzymol. 21: 470-480.

Ghysen, A. and C. O'Kane. 1989. Neural enhancer-like elements as specific cell markers in Drosophila. Development 105: $35-52$.

Ghysen, A., C. Dambly-Chaudiere, E. Aceves, L.Y. Jan, and Y.N. Jan. 1986. Sensory neurons and peripheral pathways in Drosophila embryos. Wilhelm Roux's Arch. Dev. Biol. 195: $281-289$.

Gilbert, W. 1978. Why genes in pieces? Nature 271: 501.

Go, M. 1981. Correlation of DNA exonic regions with protein structural units in haemoglobin. Nature 291: 90-92.

- 1983. Modular structural units, exons, and function in chicken lysozyme. Proc. Natl. Acad. Sci. 80: 1964-1968.

Harris, W., W. Stark, and J. Walker. 1976. Genetic dissection of the photoreceptor system in the compound eye of Drosophila melanogaster. I. Physiol. 256: 415-439.

Hartenstein, V. 1988. Development of Drosophila larval sensory organs: Spatiotemporal pattern of sensory neurons, peripheral axonal pathways and sensilla differentiation. Development 102: 869-886.
Hartley, D., T. Xu, and S. Artavanis-Tsakonas. 1987. The embryonic expression of the Notch locus of Drosophila melanogaster and the implication of point mutations in the extracellular EGF-like domain of the predicted protein. EMBO $\%$. 6: 3407-3417.

Hay, B., L.Y. Jan, and Y.N. Jan. 1988. A protein component of Drosophila polar granules is encoded by vasa and has extensive sequence similarity to ATP dependent helicases. Cell 55: $557-587$.

Hertweck, H. 1931. Anatomica und Variabilitaet des Nervensystems und der Sinnesorgane von Drosophila melanogaster (Meigen). Z. Wiss. Zool. 139: 559-663.

Hiromi, Y., A. Kuroiwa, and W. Gehring. 1985. Control elements of the Drosophila segmentation gene fushi tarazu. Cell 43: 603-613.

Jacobs, I.R. and C.S. Goodman. 1989. Embryonic development of axon pathways in the Drosophila CNS. I. A glial scaffold appears before the first growth cones. I. Neurosci. 9: 24122422.

Jacobs, J.R., Y. Hiromi, and C.S. Goodman. 1989. Lineage, migration and morphogenesis of longitudinal glia in the Drosophila CNS as revealed by a molecular lineage marker. Neuron 2: 1625-1631.

Jan, L.Y. and Y.N. Jan. 1982. Antibodies to horseradish peroxidase as specific neuronal markers in Drosophila and grasshopper embryos. Proc. Natl. Acad. Sci. 79: 2700-2704.

Jürgens, G., E. Wieschaus, C. Nüsslein-Volhard, and H. Kluding. 1984. Mutations affecting the pattern of the larval cuticle in Drosophila melanogaster. II. Zygotic loci on the third chromosome. Wilhelm Roux's Arch. Dev. Biol. 193: 283-295.

Karch, F., B. Weiffenbach, M. Peifer, W. Bender, I. Duncan, S. Celniker, M. Crosby, and E.B. Lewis. 1985. The abdominal region of the bithorax complex. Cell 43: 81-96.

Kidwell, M. 1986. P-M mutagenesis. In Drosophila, a Practical Approach (ed. D.B. Roberts), pp. 59-81. IRL Press, Oxford, Washington, D.C.

Kuner, J.M., M. Nakanishi, Z. Ali, B. Drees, E. Gustavson, J. Theis, L. Kauvar, T. Kornberg, and P. O'Farrell. 1985. Molecular cloning of engrailed: A gene involved in the development of pattern in Drosophila melanogaster. Cell 42: 309316.

Langer-Safer, P.R., M. Levine, and D.C. Ward. 1982. Immunological method for mapping genes on Drosophila polytene chromosomes. Proc. Natl. Acad. Sci. 79: 4381-4385.

Laski, F., D. Rio, and G.M. Rubin. 1986. Tissue specificity of Drosophila P-element transposition is regulated at the level of mRNA splicing. Cell 44: 7-19.

Lehmann, R., F. Jimenez, U. Dietrich, and J.A. Campos-Ortega. 1983. On the phenotype and development of mutants of early neurogenesis in Drosophila melanogaster. Wilhelm Roux's Arch. Dev. Biol. 192: 62-74.

Lehner, C. and P. O'Farrell. 1989. Expression and function of Drosophila cyclin A during embryonic cell cycle progression. Cell 56: 957-968.

Lewis, E.B. 1978. A gene complex controlling segmentation in Drosophila. Nature 276: 565-570.

Lindsley, D.L. and E.H. Grell. 1968. Genetic variations in Drosophila melanogaster. Carnegie Institute of Washington, Washington, D.C.

Maniatis, T., E.F. Fritsch, and J. Sambrook. 1982. Molecular cloning: A laboratory manual. Cold Spring Harbor Laboratory, Cold Spring Harbor, New York.

Marchionni, M. and W. Gilbert. 1986. The triosephosphate isomerase gene from maize: Introns antedate the plant-animal divergence. Cell 46: 133-141. 
Nüsslein-Volhard, C., E. Wieschaus, and H. Kluding. 1984. Mutations affecting the pattern of the larval cuticle in Drosophila melanogaster. I. Zygotic loci on the second chromosome. Wilhelm Roux's Arch. Dev. Biol. 183: 267-282.

O'Kane, C. and W. Gehring. 1987. Detection in situ of genomic regulatory elements in Drosophila. Proc. Natl. Acad. Sci. 84: 9123-9127.

Pirrotta, V. 1986. Cloning Drosophila genes. In Drosophi!a, a practical approach (ed. D.R. Roberts\}, pp. 83-110. IRL Press, Oxford, Washington D.C.

-1988. Vectors for P-medicated transformation in Drosophila. In Vectors: A survey of molecular cloning vectors and their uses (ed. R.L. Rodriguez and D.T. Denhardt), pp. 437-456. Butterworths, Boston.

Robertson, H.M., C.R. Preston, R.W. Phillis, D. JohnsonSchlitz, W.K. Benz, and W.R. Engels. 1988. A stable source of P-element transposase in Drosophila melanogaster. Genetics 118: 461-470.

Robinow, S. and K. White. 1988. The locus elav of Drosophila melanogaster is expressed in neurons at all developmental stages. Dev. Biol. 126: 294-303.

Robinow, S., A.R. Campos, K.M. Yao, and K. White. 1988. The elav gene product of Drosophila, required in neurons, has three RNP consensus motifs. Science 242: 1570-1572.

Rubin, G.M. and A. Spradling. 1982. Genetic transformation of Drosophila with transposable element vectors. Science 218: 348-353.

Rubin, G.M., M.G. Kidwell, and P.M. Bingham. 1982. The molecular basis of P-M hybrid dysgenesis: The nature of induced mutations. Cell 29: 987-994.

Schneuwly, S., R. Klemenz, and W. Gehring. 1987a. Redesigning the body plan of Drosophila by ectopic expression of the homeotic gene Antennapedia. Nature 325: 816-818.

Schneuwly, S., A. Kuroima, and W. Gehring. 1987b. Molecular analysis of the dominant homeotic Antennapedia phenotype. EMBO J. 6: 201-206.

Spradling, A. 1986. P-element-mediated transformation. In Drosophila, a practical approach (ed. D.B. Roberts), pp. 175-197. IRL Press, Oxford, Washington, D.C.

Steller H. 1984. "Gene transfer in Drosophila to study the structure, function, and regulation of cloned genes." Ph.D. thesis. University of Heidelberg.

Tomlinson, A. and D. Ready. 1987. Cell fate in the Drosophila ommatidium. Dev. Biol. 123: 264-275.

Tomlinson, A., D. Bowtell, E. Hafen, and G.M. Rubin. 1987. Localization of the sevenless protein, a putative receptor for positional information, in the eye imaginal disc of Drosophila. Cell 51: 143-150.

Uemura, T., S. Shepherd, L. Ackerman, L.Y. Jan, and Y.N. Jan. 1989. numb. A gene required in determination of cell fate during sensory organ formation in Drosophila embryos. Cell (in press).

Wieschaus, E., C. Nüsslein-Volhard, and G. Jürgens. 1984. Mutations affecting the pattern of the larval cuticle in Drosophila melanogaster. III. Zygotic loci on the X-chromosome and fourth chromosome. Wilhelm Roux's Arch. Dev. Biol. 193: $296-307$.

Whitfield, W., C. Gonzalez, E. Sanchez-Herrero, and D. Glover. 1989. Transcripts of one of two Drosophila cyclin genes become localized in pole cells during embryogenesis. Nature 338: $337-340$.

Ziemer, A., K. Tietze, E. Knust, and J.A. Campos-Ortega. 1988. Genetic analysis of Enhancer of split, a locus involved in neurogenesis in Drosophila melanogaster. Genetics 119: $63-74$. 


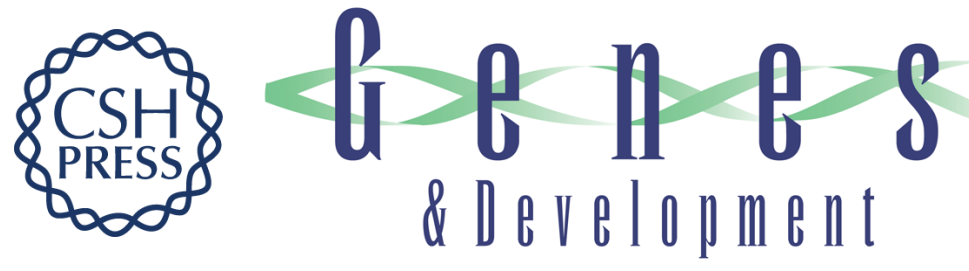

\section{Searching for pattern and mutation in the Drosophila genome with a P-lacZ vector.}

E Bier, H Vaessin, S Shepherd, et al.

Genes Dev. 1989, 3:

Access the most recent version at doi:10.1101/gad.3.9.1273

References This article cites 55 articles, 16 of which can be accessed free at: http://genesdev.cshlp.org/content/3/9/1273.full.html\#ref-list-1

License

Email Alerting

Service

Receive free email alerts when new articles cite this article - sign up in the box at the top right corner of the article or click here.

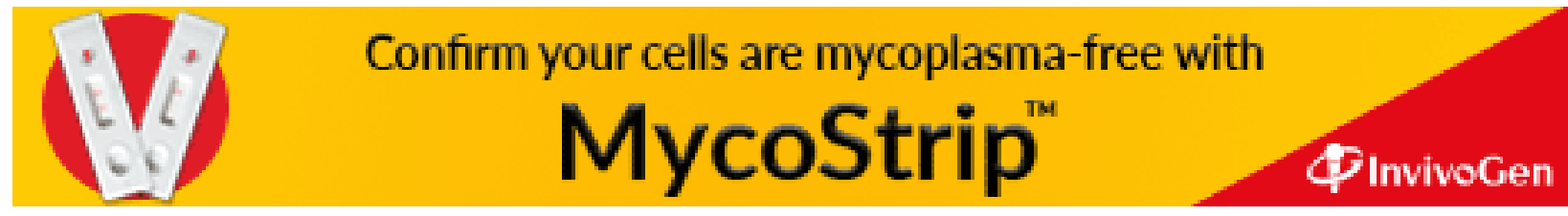

